\title{
IMPLEMENTASI KEBIJAKAN PEMERINTAH TENTANG PENGALOKASIAN DANA PAJAK DARI PENERIMAAN PAJAK PENERANGAN JALAN TERHADAP PENYEDIAAN PENERANGAN JALAN UMUM DI KABUPATEN MINAHASA
}

\author{
Regina M. Mangirang ${ }^{1}$, Jullie J. Sondakh ${ }^{2}$, Robert Lambey $^{3}$ \\ ${ }^{1,2,3}$ Fakultas Ekonomi dan Bisnis, Jurusan Akuntansi, Universitas Sam Ratulangi, Jl. Kampus Bahu, Manado, \\ 95115, Indonesia \\ E-mail : mangirangregina@gmail.com
}

\begin{abstract}
Earmarking Tax is the allocation of a certain amount of local revenue (especially tax) to fund public services in accordance with the type of tax levied. One type of tax from this policy is street lighting taxes whose funds are allocated for the provision of street lighting. Special street lighting tax no minimum amount should be allocated to ensure the availability of funds, then only adjust to the needs of the region. The purpose of this study is to analyze the implementation earmarking tax funds from street lighting tax revenue on the provision of street lighting in Minahasa District. The method used is qualitative descriptive method. From the research results can be seen that the policy of appropriation of tax funds has been applied in accordance with existing regulations in Minahasa regency as regulated in Minahasa District Regulation No. 1 of 2011 this is because more than a portion of funds from street lighting tax revenue has been allocated for the provision of lighting road that is equal to 57,55\%. Earmarking tax in Minahasa District goes hand in hand with the APBD system, which is through the regional public treasury in terms of income and expenditure.
\end{abstract}

Keywords: Earmarking Tax, street lighting tax.

\section{PENDAHULUAN}

Undang-Undang Nomor 32 Tahun 2004 tentang pemerintah daerah merupakan suatu landasan yuridis bagi pengembangan otonomi daerah di Indonesia. Dalam undang-undang ini disebutkan pengembangan otonomi pada daerah kabupaten dan kota diselenggarakan dengan memperhatikan prinsip-prinsip demokrasi, peran serta masyarakat, pemerataan keadilan, serta memperhatikan potensi dan keanekaragaman daerah. Otonomi daerah selain memberikan kewenangan kepada daerah untuk mengatur dan mengurus sendiri urusan pemerintahan juga memberikan kewenangan kepada daerah untuk mengatur keuangan daerahnya melalui desentralisasi fiskal. Desentralisasi fiskal di Indonesia secara khusus diatur dalam UndangUndang Nomor 32 Tahun 2004 tentang perimbangan keuangan antara pemerintah pusat dan daerah. Sejalan dengan hal tersebut, kebijakan desentralisasi fiskal di Indonesia harus disertai dengan penyerahan dan pengalihan pembiayaan, sarana dan prasarana, serta sumber daya manusia sesuai dengan kewenangan yang diserahkan tersebut. Tanpa adanya pembiayaan yang memadai, maka suatu daerah tidak akan dapat optimal dalam menjalankan kewenangan yang dideklarasikan kepadanya. Dalam menjalankan perannya sebagai pelayanan publik, pemerintah daerah membutuhkan pendanaan yang memadai.

Pendapatan Asli Daerah (PAD) merupakan salah satu komponen pembiayaan yang sangat penting dalam proses implementasi desentralisasi fiskal. Hal ini dikarenakan Pendapatan Asli Daerah (PAD) mencerminkan kemandirian daerah tersebut dalam menjalankan prinsip-prinsip otonomi daerah. PAD yang diamanatkan dalam Undang-Undang No. 33 Tahun 2004 tentang Perimbangan Keuangan antara Pemerintah Pusat dan Pemerintah Daerah yang terdiri atas Pajak Daerah, Retribusi Daerah, Hasil Pengelolaan Kekayaan Daerah yang dipisahkan, dan lain-lain PAD yang sah diatur berdasarkan peraturan yang berlaku. Bila dibandingkan dengan sumber pendapatan lain dalam PAD, pajak merupakan 
bagian yang sangat berpengaruh dalam PAD yang dapat dikatakan sebagai sumber pendapatan yang besar bagi daerah, sehingga pajak mengambil peran penting dalam hal pengimplementasian desentralisasi dan otonomi daerah.

Undang-Undang Nomor 28 Tahun 2009 merupakan perubahan kedua dari UndangUndang Pajak Dan Retribusi Daerah, dimana diawali dengan Undang-Undang Nomor 18 Tahun 1997 dan mengalami perubahan pertama menjadi Undang-Undang Nomor 34 tahun 2000. Dalam Undang-Undang ini terdapat perbedaan dengan Undang-Undang sebelumnya seperti penambahan atau pengalihan jenis pajak serta pengaturan mengenai pengalokasian dana dari beberapa jenis pajak. Salah satu yang menjadi hal baru dan tidak diatur dalam Undang-Undang sebelumnya adalah mengenai alokasi dari beberapa jenis pajak daerah. Pengalokasian dana pajak, penerapannya dilakukan untuk membiayai kegiatan yang berkaitan dengan pajak yang dipungut. Salah satu jenis pajak daerah yang wajib dialokasikan dananya dalam peraturan ini yaitu pajak penerangan jalan untuk penyediaan penerangan jalan umum.

Di kabupaten Minahasa pada tahun 2016 telah dialokasikan dana untuk penyediaan penerangan jalan umum sebesar Rp. 4.805.000.000 atau mencapai 57,55\% dari keseluruhan penerimaan pajak penerangan jalan, namun hingga saat ini masih terdapat lampu jalan yang rusak atau tidak berfungsi sebagaimana mestinya sehingga menyebabkan kerugian bagi masyarakat Kabupaten Minahasa apalagi bagi masyarakat yang melakukan aktivitas pada malam hari. Adapun penelitian bertujuan untuk mengetahui penerapan kebijakan pengalokasian dana pajak dari penerimaan pajak penerangan jalan di Kabupaten Minahasa sudah sesuai dengan peraturan yang berlaku.

\section{TINJAUAN PUSTAKA}

\section{1. Konsep Akuntansi}

Rudianto (2012 : 5) dalam bukunya memaparkan Akuntansi adalah sistem informasi yang menghasilkan informasi keuangan kepada pihak-pihak yang berkepentingan mengenai aktivitas ekonomi dan kondisi suatu perusahaan.

Selain itu terdapat pengertian lain mengenai pengertian akuntansi menurut Pura (2013:4) yaitu seperangkat pengetahuan yang mempelajari perekayasaan dalam penyediaan jasa, yang berupa informasi keuangan kuantitatif dari suatu unit organisasi dan cara penyampaian (pelaporan) informasi tersebut kepada pihak yang berkepentingan untuk dijadikan dasar pengambilan keputusan ekonomi". Dengan demikian akuntansi adalah proses pencatatan, penggolongan, peringkasan dan penyajian dengan cara-cara tertentu terhadap transaksi keungan yang terjadi dalam perusahaan atau organisasi lainnya serta interprestasinya terhadap hasilnya.

\subsection{Akuntansi Keuangan Daerah}

Menurut M. Ramli (2016: 10) akuntansi pemerintahan merupakan salah satu bidang ilmu yang pesat perkembangannya dalam beberapa tahun terakhir ini. Pesatnya kemajuan tersebut menuntut imbangan pada penyediaan informasi akuntansi yang memadai. Selain itu, adanya tuntutan akuntabilitas dan transparansi yang dihadapi pemerintah pusat maupun pemerintah daerah menjadikan akuntansi pemerintahan sangat penting.

\section{3. Pajak Daerah}

Pengertian pajak menurut Soemitro, dalam Mardiasmo (2013:1) bahwa pajak adalah iuran rakyat kepada kas negara berdasarkan undang-undang (yang dapat dipaksakan) dengan tiada mendapat jasa timbal (kontraprestasi) yang langsung dapat ditunjukkan dan yang digunakan untuk membayar pengeluaran umum.

\section{4. Alokasi Pajak (Earmarking Tax)}

Alokasi pajak merupakan praktik umum yang merupakan salah satu pendekatan dalam bidang pengelolaan keuangan publik, khususnya bidang penganggaran atau pengalokasian belanja. Istilah Alokasi pajak dalam konteks pengelolaan keuangan publik 
didefinisikan sebagai suatu kondisi dimana sumber pendapatan Negara tertentu dialokasikan kepada kegiatan pelayanan publik tertentu. Alokasi pajak sering dikaitkan dalam konteks perpajakan sehingga kemudian muncul dan populer earmarked taxes.

Pengalokasian dana pajak adalah pajak yang dipungut untuk membiayai pengeluaranpengeluaran tertentu yang sudah spesifik. Menurut Ismail, aloksi pajak adalah kontraprestasi yang sesuai peruntukkannya dan harus ditentukan dalam UU maupun peraturan pelaksanaannya (Perda), sehingga terdapat kepastian mengenai adanya kewajiban kontraprestasi berupa pelayanan dan besarnya presentase yang dialokasikan untuk pelayanan jenis pajak bersangkutan.

\subsection{Pajak Penerangan Jalan}

Pajak penerangan jalan merupakan salah satu pajak daerah sebagai konsekuensi logis dari penetapan ketentuan Undang-Undang Pajak Daerah dan Retribusi Daerah yang baru dalam kaitannya dengan peningkatan kinerja pemungutan. (Driyana, Jullie, Anneke). Lahirnya jenis pajak ini disebabkan oleh suatu pertimbangan bahwa pemerintah daerah memerlukan biaya cukup besar dimana selama ini ditanggung pemerintah daerah (Pemda). Salah satunya adalah pembiayaan dalam hal penerangan jalan umum. Sarana penerangan jalan yang disediakan Pemda dimaksudkan untuk peningkatan kesejahteraan masyarakat khususnya demi keamanan, ketertiban, dan kesegaran kehidupan kota.

\subsection{Penelitian Terdahulu}

Penelitian terdahulu ini menjadi salah satu acuan peneliti dalam melakukan penelitian sehingga peneliti dapat memperkaya teori yang dapat digunakan dalam mengkaji penelitian yang dilakukan peneliti.

\section{METODE PENELITIAN}

\subsection{Jenis Penelitian}

Metode analisis yang digunakan untuk membahas permasalahan dalam penelitian ini adalah metode analisis deskriptif kualitatif. Metode penelitian kualitatif didefinisikan sebagai suatu analisis berdasarkan data yang diperoleh, selanjutnya dikembangkan pola hubungan tertentu atau menjadi hipotesis.

\subsection{Metode Analisis}

Berdasarkan tujuannya, penelitian ini termasuk dalam penelitian deskriptif (descriptive research). Penelitian deskriptif merupakan penelitian terhadap masalah-masalah berupa fakta-fakta saat ini dari suatu populasi (Indriantoro \& Supomo, 2012 : 26). Penelitian ini diklasifikasikan berdasarkan tujuan dan tingkat kealamian objek yang diteliti. (Sugiono $2013: 4)$.

\section{HASIL PENELITIAN}

\subsection{Pengaturan Alokasi Dana Pajak Penerangan Jalan Kabupaten Minahasa.}

Pajak penerangan jalan merupakan salah satu jenis pajak yang pengalokasian dana pajaknya diatur dalam Perda Kabupaten Minahasa Nomor 1 Tahun 2011 yang memiliki persamaan pengaturan dengan Undang-Undang Nomor 28 Tahun 2009. Dalam pasal 13 menyatakan bahwa sebagian dari penerimaan pajak penerangan jalan harus dialokasikan untuk penyediaan penerangan jalan umum.

Pemungutan pajak penerangan jalan dilakukan oleh Badan Pengelola Pajak dan Retribusi Daerah Kabupaten Minahasa yang bekerjasama dengan PLN dalam hal ini PLN wajib menerima dan menyetor penerimaan pajak penerangan jalan ke kas daerah di Bank BNI dan diawasi dan dipantau oleh Badan Pengelola Pajak dan Retribusi Daerah Kabupaten Minahasa. Untuk itu Badan Pengelola Pajak dan Retribusi Daerah Kabupaten Minahasa melaksanakan with holding system dengan PLN. Khusus untuk pajak penerangan jalan Badan Pengelola Pajak dan Retribusi Daerah Kabupaten Minahasa tidak memegang uang secara langsung karena untuk pajak penerangan jalan disetorkan ke kas daerah di Bank BNI. 
Alokasi pajak penerangan jalan untuk penyediaan sarana prasarana penerangan jalan umum belanjanya diatur oleh Dinas perumahan Rakyat dan Kawasan Permukiman Kabupaten Minahasa. Maka rancangan untuk belanja pengaturannya oleh SKPD ini, akan telihat besaran nominal dalam struktur APBD untuk belanja penyediaan sarana prasarana penerangan jalan umum. Dalam membiayai belanja tersebut juga menggunakan dana yang telah dirancang dalam APBD. Badan Pengelola Keuangan dan Aset Daerah Kabupaten Minahasa dalam hal ini akan menyetor dana untuk belanja ke SKPDnya dan penyetoran dana didasarkan kepada jumlah anggaran untuk SKPD. Hal ini menunjukkan dana pajak penerangan jalan secara keseluruhan masuk bersama dengan PAD lainnya sudah tidak terlihat jumlah nominal yang telah dialokasikan untuk penyediaan sarana prasarana penerangan jalan umum, khusus pajak penerangan jalan tidak ada batasan minimum alokasinya.

Tabel 4.1

Penerimaan PPJ Kabupaten Minahasa Tahun 2016

\begin{tabular}{|l|l|l|l|l|}
\hline No & \multicolumn{1}{|c|}{$\begin{array}{c}\text { Unit } \\
\text { Pengelola/ } \\
\text { Jenis } \\
\text { Penerimaan }\end{array}$} & Target TA. 2016 & $\begin{array}{c}\text { Realisasi Tahun } \\
\mathbf{2 0 1 6}\end{array}$ & $\begin{array}{c}\text { \% dari } \\
\text { target }\end{array}$ \\
\hline 1 & BP2RD + PPJ & $\operatorname{Rp~} 32.652 .009 .650$ & $\mathrm{Rp} \mathrm{36.970.459.178}$ & $113,23 \%$ \\
\hline 2 & BP2RD & $\mathrm{Rp} \mathrm{25.352.009.650}$ & $\mathrm{Rp} \mathrm{28.622.138.479}$ & $112,90 \%$ \\
\hline 3 & $\begin{array}{l}\text { Pajak } \\
\text { Penerangan } \\
\text { jalan }\end{array}$ & $\mathrm{Rp} 7.300 .000 .000$ & $\mathrm{Rp} .8 .348 .320 .695$ & $114,37 \%$ \\
\hline
\end{tabular}

Sumber : Badan Pengelola Pajak dan Retribusi Daerah Kabupaten Minahasa (diolah kembali oleh peneliti)

Tabel 4.1 menunjukkan bahwa penerimaan pajak penerangan jalan di Kabupaten Minahasa pada tahun 2016 adalah sebesar Rp. 8.348.320.695 atau 114,37\% dari target tahun anggaran 2016. Untuk alokasi pajak khusus pajak penerangan jalan tidak memiliki besaran minimum alokasi jadi jumlah nominal minimum yang harus dialokasikan tidak ada. Maka dapat dikatakan bahwa anggaran untuk belanja dalam hal penyediaan sarana prasarana penerangan jalan umum harus menyesuaikan dengan kebutuhan dari Rp. 8.348.320.695 yang harus dialokasikan.

\subsection{Belanja Untuk Penyediaan sarana prasarana Penerangan Jalan Umum Kabupaten Minahasa Tahun 2016}

Penyediaan sarana prasarana di Kabupaten Minahasa merupakan salah satu kegiatan belanja langsung yang diatur dalam rancangan APBD dan dijadikan prioritas yang terutama dalam hal pemasukan dana pajak penerangan jalan. Di Kabupaten Minahasa yang melakukan belanja langsung dalam hal penyediaan penerangan jalan ini yaitu Dinas Perumahan Rakyat dan Kawasan Permukiman Kabupaten Minahasa.

Penyediaan sarana prasarana penerangan jalan umum di Kabupaten Minahasa di dasarkan pada kebutuhan untuk pembiayaannya, jadi besaran dana yang yang dikeluarkan adalah nominal yang dibutuhkan daerah Kabupaten tersebut. Besaran minimal yang wajib dialokasikan menjadi jaminan ketersediaan dana untuk daerah dalam membiayai sektor tersebut namun pajak penerangan tidak memiliki besaran minimum yang wajib dialokasikan sehingga hanya menyesuaikan dengan kebutuhan daerah.

Target dan belanja langsung untuk penyediaan sarana prasarana penerangan jalan umum di Kabupaten Minahasa pada tahun 2016 terlihat pada tabel 4.2. 


\section{Tabel 4.2}

Target dan Pengeluaran Untuk Program Pengadaan/Penyediaan Penerangan Jalan Umum di Kabupaten Minahasa tahun 2016

\begin{tabular}{|c|l|c|r|}
\hline No & \multicolumn{1}{|c|}{ Uraian } & Anggaran 2016 & Realisasi 2016 \\
\hline 1 & $\begin{array}{l}\text { Penerangan lampu jalan } \\
\text { (sistem solar cell) }\end{array}$ & Rp 4.862.000.000 & Rp 4.605.000.000 \\
\hline & Jumlah & Rp 4.862.000.000 & Rp 4.605.000.000 \\
\hline
\end{tabular}

Sumber : Dinas Perumahan rakyat dan kawasan permukiman Kabupaten Minahasa (diolah kembali oleh peneliti)

Tabel 4.2 menunjukkan jumlah target atau anggaran untuk penyediaan penerangan jalan umum untuk tahun 2016 sebesar Rp. 4.862.000.000 dan realisasinya sebesar Rp. 4.805.000.000.

\subsection{Pembahasan Hasil Penelitian}

Pajak penerangan jalan termasuk dalam Pendapatan Asli Daerah yang dipungut oleh PLN yang diawasi oleh Badan Pengelola Pajak dan Retribusi Daerah Kabupaten Minahasa. Pelaksanaan kebijakan pengalokasian dana pajak di Kabupaten Minahasa didasarakan pada Undang-Undang Nomor 28 Tahun 2009 tentang Pajak Daerah dan Retribusi daerah, lalu di jabarkan dalam Perda Kabupaten Minahasa Nomor 1 Tahun 2011 tentang pajak daerah, sehingga pelaksanaan kebijakan perpajakan yang sampai saat ini di Kabupaten Minahasa baru diberlakukan sejak tahun 2012.

Pajak penerangan jalan di Kabupaten Minahasa pemungutannya dari penyetoran pajak oleh wajib pajak dipungut oleh PLN yang kemudian dananya dikumpulkan oleh Badan Pengelola Pajak dan Retribusi Daerah Kabupaten Minahasa bersamaan dengan dana pajak lain Kabupaten Minahasa. Dana Pajak Penerangan Jalan yang masuk dalam kas daerah bersamaan dengan jenis penerimaan pajak dan pendapatan lainnya, dalam bentuk pendapatan asli daerah melalui Badan Pengelola Pajak dan Retribusi Daerah yang kemudian pengelolaannya melalui Badan Pengelola Keuangan dan Aset Daerah Kabupaten Minahasa.

Semua jenis PAD akan masuk secara seluruhnya ke kas daerah lalu penyetoran dana untuk kegiatan belanja daerah ditransfer berdasarkan jumlah dalam rancangan APBD ataupun kebutuhan daerah yang telah disepakati berdasarkan peraturan. Hal ini menunjukkan nilai yang harus dialokasikan untuk penyediaan penerangan jalan umum tidak akan terlihat karena dana alokasi ini belum memiliki rekening khusus sehingga dana alokasi pajak penerangan jalan ini disetorkan dalam kas daerah yang pengeluaranya berjalan dengan APBD. Adapun pajak penerangan jalan tidak memiliki besaran minimum yang harus dialokasikan sehingga menyesuaikan dengan kebutuhan daerah. Jenis pajak yang di-earmark lainnya selain memiliki besaran minimum untuk menjamin ketersediaan dana juga harus menyesuaikan dengan kebutuhan dari daerah sehingga nominal yang harus dialokasikan bisa lebih.

Sesuai dengan hasil penelitian, maka jumlah realisasi penerimaan dan bagi hasil pajak penerangan jalan serta jumlah belanja dalam penyediaan penerangan jalan di Kabupaten Minahasa pada tahun 2016 yang menunjukkan hubungan antara keduanya dalam kaitannya dengan kebijakan alokasi pajak ditunjukkan pada tabel 4.3. 


\section{Tabel 4.3}

Penerimaan PPJ dan Belanja Penyediaan Penerangan Jalan Kabupaten Minahasa Tahun 2016.

\begin{tabular}{|c|c|c|c|}
\hline $\begin{array}{c}\text { Penerimaan PPJ } \\
\text { Keseluruhan }\end{array}$ & Alokasi Pajak & $\begin{array}{c}\text { Pengeluaran untuk } \\
\text { penyediaan } \\
\text { penerangan jalan }\end{array}$ & Dalam \% \\
\hline Rp8.348.320.695 & $\begin{array}{c}\text { Tidak ada nilai } \\
\text { minimum }\end{array}$ & Rp4.805.000.000 & $57,55 \%$ \\
\hline
\end{tabular}

Sumber : Data diolah (2017)

Tabel 4.3 menunjukkan bahwa untuk belanja dalam hal penyediaan penerangan jalan untuk tahun 2016 adalah senilai Rp 4.805.000.000. Dalam kaitannya dengan Alokasi pajak hal ini menunjukkan sudah ada sebagian dari dana PPJ yang masuk di kas daerah dialokasikan untuk penyediaan sarana prasarana penerangan jalan umum. Dana yang digunakan untuk belanja penyediaan penerangan jalan perhitungannya :

PPJ keseluruhan :

Presentase $(\%)=(\operatorname{Rp} 4.805 .000 .000: \operatorname{Rp} 8.348 .320 .695) 100 \%=57,55 \%$

Dengan demikian, dana yang digunakan untuk belanja penyediaan penerangan jalan umum besaran alokasinya yaitu mencapai 57,55\% dari penerimaan Pajak Penerangan Jalan di Kabupaten Minahasa secara keseluruhan untuk tahun 2016. Sehingga dapat dikatakan bahwa Kabupaten Minahasa telah mengeluarkan dana untuk belanja penyediaan penerangan jalan umum.

\section{KESIMPULAN DAN SARAN}

\subsection{Kesimpulan}

Berdasarkan hasil penelitian dan pembahasan maka dapat ditarik kesimpulan bahwa penerapan kebijakan pengalokasian dana pajak dari penerimaan pajak penerangan jalan terhadap penyediaan penerangan jalan umum di Kabupaten Minahasa sudah sesuai dengan Peraturan Daerah Kabupaten Minahasa Nomor 1 Tahun 2011. Hal ini ditunjukkan oleh belanja untuk sarana dan prasarana untuk penyediaan penerangan jalan umum yang dilakukan oleh dinas perumahan rakyat dan kawasan permukiman pada tahun 2016 mencapai 57.55\% dari penerimaan Pajak Penerangan Jalan yang masuk ke kas daerah.

\subsection{Saran}

Berdasarkan kesimpulan diatas peneliti memberikan saran sebagai berikut :

1. Kualitas pelayanan publik yang diberikan oleh pemerintah daerah terutama penerangan jalan umum lebih ditingkatkan dan dipertahankan pengelolaannya, sehingga lampu-lampu penerangan jalan mampu berfungsi sebagaimana mestinya dan jumlah penerangan jalan di Kabupaten Minahasa bisa mencapai setiap area.

2. Lampu-lampu yang mengalami kerusakan pemerintah daerah diharapkan bisa menanggulanginya demi kesejahteraan warga Kabupaten Minahasa dalam beraktivitas terutama pada malam hari.

3. Untuk kebijakan pengalokasian dana pajak alangkah baiknya jika ditentukan nilai minimum dalam pengalokasian.

4. Untuk penyediaan penerangan jalan umum dan kiranya menetapkan standar operasional prosedur (SOP), pengawasan atas kebijakan ini sehingga dapat dilakukan sebagaimana mestinya. 
5. Lebih meningkatkan sosialisasi sehingga bisa lebih banyak masyarakat Kabupaten Minahasa yang mengetahui tentang kebijakan ini.

\section{DAFTAR PUSTAKA}

Bird, Ricard M. and Joosung Jung, 2005. Earmarking In The Theory Practice. ITP Paper, 0513

Indriantoro, Supomo 2012. Metode Penelitian Bisnis Untuk Akuntansi dan Manajemen, Edisi Pertama

Mardiasmo. 2013. Perpajakan Edisi Revisi, Andi Offset, Yogyakarta

Rudianto. 2012. Pengantar Akuntansi Adaptasi IFRS. Erlangga : Jakarta

Pura, Rahman.2013.Pengantar Akuntansi 1: Pendekatan Siklus Akuntansi.Erlangga : Jakarta.

Peraturan Daerah (PERDA) Kabupaten Minahasa Nomor 1 Tahun 2011 Tentang Pajak Daerah

Ramli M. 2016. Pengantar Akuntansi Keuangan Daerah. Ghalia Indonesia

Sari Diana, 2013. Konsep Dasar Perpajakan. PT refika Adimata. Bandung halaman

Undang-Undang Nomor 22 Tahun 1999 tentang Pemerintah Daerah.

Undang-Undang Nomor 28 Tahun 2009 Tentang Pajak Daerah dan Retribusi Daerah (PDRD). 2009. Jakarta.

Undang-Undang Nomor 32 Tahun 2004 tentang Pemerintahan Daerah.

Undang-Undang Nomor 33 Tahun 2004 Tentang Perimbangan Pusat dan Daerah. 